\title{
What is a trial?
}

\author{
Joseph Jaconelli
}

\section{Three questions}

To pose the question, 'What is a trial?', is to invite an answer which aims to transcend particular times, places and cultures. It is to suggest that, stripped of the rules that are peculiar to particular legal systems, those processes that are properly called 'trials' contain some inner essence. It is to claim that the proceedings against Socrates under Athenian law in $399 \mathrm{BC}$ and those brought against Jesus in AD 30 under Jewish and Roman legal procedures have features in common with the televised ordeal of O. J. Simpson in a Los Angeles courtroom two thousand years later.

'What is a trial?' is a question that has seldom engaged the interest of lawyers. Yet the concept of a trial is central to some of the most fundamental ideas about human rights. Imprisonment, or internment, without trial is regarded as abhorrent and capable of being justified only by the most pressing needs of wartime or national emergency. If a person is to be deprived of his liberty, it is widely felt, this should occur only as the result of a more open and formal process than the exercise of the discretion of a government official. Indeed, the use of the term 'trial' in human rights charters, particularly in those international documents to which a number of nations subscribe, raises the possibility of exploring the essence of the institution across a variety of cultures. These charters typically guarantee such rights as those to a speedy trial, ${ }^{1}$ a fair trial, ${ }^{2}$ a public trial, ${ }^{3}$ trial by jury, ${ }^{4}$ or (to quote from chapter 29 of Magna Carta) a trial conducted according to the judgment of one's peers. ${ }^{5}$ The guarantees may be listed singly, or in combination (as, for example, with the United States Sixth Amendment's assurance of 'the right to a speedy and public trial'). In each case, however, it is the adjective (speedy, fair, public) or adjectival phrase (by jury, according to the judgment of one's peers) that bears the brunt of interpretative dispute. In regard to some of the qualifying words it is inevitably so. It would, for example, be difficult to envisage a verdict-producing process which, though qualifying as 'fair', did not amount 
to a 'trial'. In other cases, however, there is no necessary link between the adjective and the concept of a 'trial'. This is implicit in the comment on the guarantees of the Sixth Amendment by the US Supreme Court in Estes v. Texas: ${ }^{6}$

Significantly, in the Sixth Amendment the words 'speedy and public' qualify the term trial and the rest of the Amendment defines the specific protections the accused is to have at his trial. Thus, the Sixth Amendment, by its own terms, not only requires that the accused have certain specific rights but also that he enjoy them at a trial ...?

In another respect, also, the concept of a 'trial' occupies a central position in human rights charters. Some provisions of these documents, without using the word, implicitly assume the existence of the trial process. One example is the frequently encountered ban on retrospective criminal laws. ${ }^{8}$ Such laws, unless they are brought to bear in the trial of particular individuals, scarcely embody the mischief with which they are traditionally associated. The rule against double jeopardy ${ }^{9}$ presupposes the holding of an earlier trial. The prohibition of "excessive bail'10 assumes a pre-trial period, and that of "cruel and unusual punishments" ${ }^{11}$ limits the range of sanctions that may be inflicted on the convicted accused. ${ }^{12}$ Other guarantees - for example, the right to crossexamine hostile witnesses, or the right to the assistance of counsel ${ }^{13}-$ are fully intelligible only within the trial setting.

If the question of what is a trial appears not to have occasioned much controversy, two related questions - What is a 'court'? What is a 'judicial' function? - have engaged the attention of legal writers.

The first of these issues has been the subject of historical analysis. ${ }^{14}$ The concept of a 'court', which originally was not confined to that of a court of law, ${ }^{15}$ now reflects a number of ideas associated with the administration of justice: as a physical location (the Royal Courts of Justice situated in the Strand); as an entity that exists for the purpose of transacting business ('The court is now adjourned'); as an entity that has a continuous existence (in the description of persons as 'officers of the court'); or as the personification of the judges who sit in it ("This court takes a dim view of your conduct'). ${ }^{16}$ The unspoken assumption that courts form part of the machinery of the state scarcely required emphasis at a time when judicial authority was not fully differentiated from legislative authority and the administration of affairs in general. ${ }^{17}$

Once that process of differentiation started to occur, the question, 'What is a judicial function?', began to attract a substantial amount of attention. There have been many reasons why this should be so. Those written constitutions that embody the idea of the separation of powers must perforce have some understanding of what is the occasion of the exercise of 'judicial' power, in contrast to that of a 'legislative' or 'administrative' power. At the sub-constitutional level, there are various privileges associated with judicial 
functions. Those charged with their exercise might be exempted from civil liability for actions taken in the course of performing them. Or those who report the proceedings of a judicial body - typically the media - may enjoy immunities from forms of liability (e.g. defamation, contempt of court) that would otherwise attach to their publications. Sometimes, by contrast, there are more exacting procedural standards demanded of bodies that are classified as judicial: in particular, the duty to observe the standards of natural justice. Indeed, the rules of natural justice themselves embody in rudimentary form the standards that would be expected of any court. ${ }^{18}$ First, the right to a hearing (audi alteram partem) reflects the idea of effective participation in the decision-taking process through such means as: attendance at the hearing; the making of representations; and, if necessary, legal representation. Secondly, those who adjudicate on the issue must be free of bias, or even the appearance of bias, against any of the parties ('no one to be judge in his own cause', nemo iudex in causa sua).

Not all occasions on which 'judicial' functions are exercised may properly be described as trials. Nevertheless, an analysis of what constitutes a judicial function will form a convenient starting point. A leading work on administrative law propounds three guidelines. ${ }^{19}$

First, the exercise of a judicial function ends in the making of an order that has conclusive effect. That, in itself, is not particularly helpful, but it does draw attention to the fact that the result of legal proceedings is not, as a general rule, subject to confirmation by a person or body outside the court. Certainly, the outcome may be subject to appeal to another body that is charged with judicial tasks. Once the processes of appeal are exhausted, however, there is usually some procedural bar to relitigating them, expressed in such legal doctrines as the rule against double jeopardy. This does not, of course, preclude discussion at large as to whether the correct result was reached - a question on which, in the more controversial cases, there may be vigorous debate down the years.

Secondly, does the body in question possess the trappings and procedures normally associated with a court? In other words, does it look like a court? Are matters decided by the body only when they have been initiated by parties? Does the body hold sittings? Does it do so in public? Can an adverse ruling result in the imposition of sanctions?

Thirdly, does the body resolve disputed questions of law and issues of fact? In particular, the applicable legal rules must exist prior to the facts of the dispute that give rise to the need for adjudication. This element reflects the central role of courts as institutions essential to the rule of law, forming the link between general legal norms and their application to the resolution of particular disputes.

However, the questions, 'What is a court?' and 'What is a judicial function?', are both wider and narrower than the central concern of this chapter: 'What is a trial?' 
They are too wide because, in the first place, ordinary language usage appears to restrict the word 'trials' to hearings at first instance. That is, the term does not appear apposite to cover the appellate stages of proceedings, even though these are undoubtedly judicial in nature and are conducted in institutions that are clearly recognisable as courts. Hence the distinction commonly drawn between 'trial courts' and 'appellate courts'. In other words, the resolution of contested issues of fact appears to be essential to the concept of a trial. The questions are too wide in a further respect, in that the natural meaning of the word 'trial' is confined to proceedings that are criminal in nature. The word may be taken, by extension, to include those civil proceedings where an adverse judgment of the court has catastrophic consequences for an individual's general reputation and standing. Actions for defamation, clearly, are cases that may be categorised in this way. However, any type of civil case which, according to the temper of the times, will have such far-reaching consequences may properly be included in the category. ${ }^{20}$ Prominent examples from nineteenth-century British history are those marital cases (in particular, the trial of divorce petitions) which brought great scandal on those whose conduct was condemned in the proceedings. It was cases of this type which were responsible for wrecking the political career of Charles Stewart Parnell in 1890 and, more remarkably still, that of Sir Charles Dilke several years earlier. $^{21}$

At the opposite extreme, the concepts of 'court' and 'judicial function' are in certain respects too narrow. For, arguably, they fail to capture processes that might properly be regarded as 'trials' even though they are conducted in the legislature.

The House of Lords, as the upper house of Parliament, long conducted proceedings that were recognisable as judicial. Under chapter 29 of Magna Carta, a peer of the realm could not be tried by commoners but only by his fellow peers. The privilege, which extended to charges of treason and felony (but not misdemeanours), was last used in $1935 .^{22}$ The following year, with memories still fresh of the difficulties that could have arisen in connection with the holding of such a trial, initiatives were taken in the House of Lords to put an end to the privilege. It was not, however, until 1948 that it was abolished. $^{23}$

In contrast, it is common to describe as the 'Trial of Queen Caroline' the proceedings brought in 1820 to dissolve Queen Caroline's marriage to King George IV and to deprive her of her title, rights and privileges. ${ }^{24}$ Outwardly the process was legislative in nature, centring on a 'Bill of Pains and Penalties' which incorporated a divorce clause. ${ }^{25}$ The Bill started in the House of Lords, and in due course would have proceeded to the House of Commons. In substance, however, the proceedings could be viewed as judicial. The issue was whether Queen Caroline, as alleged in the Bill's preamble, had committed adultery. To this end witnesses were called and examined; counsel were deployed to argue the case on either side; and the event was presided over by the 
Lord Chancellor, Lord Eldon - although (in violation of the normal standards of judicial impartiality) he spoke and voted in favour of one side in the debate. The end to the Bill was decidedly political, withdrawn by the Government in the light of the slender majorities in the Bill's favour in the House of Lords and with the prospect of intense opposition to it when it reached the Commons.

Further instances of legislative proceedings that bear some of the characteristics of a judicial procedure are provided by Bills of Attainder and, more topically, by the impeachment process. The latter has twice been deployed, unsuccessfully, against a president of the USA: against Johnson in 1868, and Clinton in 1998-99. In both its English and American forms the impeachment procedure bears some of the traits of a trial. In particular, the accusation is framed by the lower house (the House of Commons, the House of Representatives) and the matter is tried before the upper house (the House of Lords, the Senate).$^{26}$ The provisions of the US Constitution that regulate the process of impeachment use the terminology of the criminal law. Removal from office is to take place on "impeachment for, and conviction of, treason, bribery, or other high crimes and misdemeanours, ${ }^{27}$ It is also provided that 'the trial of all crimes, except in cases of impeachment, shall be by jury'. ${ }^{28}$ In stark contrast is the provision that no person, whether a president or otherwise, is to be convicted without 'the concurrence of two thirds of the members present'. ${ }^{29}$ Therefore, although the vocabulary of crime is used in delineating the process, the requirement of a two-thirds majority (in contrast to the requirement of simple majority or unanimity) reflects the essentially political nature of impeachment as a means of exercising control over public officials. ${ }^{30}$

Bills of Attainder, on the other hand, are expressly forbidden by the US Constitution, where they are mentioned in the same breath as retrospective laws. ${ }^{31}$ In historical terms, attainder referred to the penalties incurred as a result of conviction for treason or felony, in particular the 'corruption of blood' which forbade the inheritance of land down the family line. The American conception of a Bill of Attainder, however, is of 'a legislative act which inflicts punishment without a judicial trial'. ${ }^{32}$ Yet it is clear from their English origins that, although some Acts of Attainder were legislative substitutes for what should have been judicial proceedings, others were enacted after their subjects had been found guilty at an ordinary trial. ${ }^{33}$

At the other extreme, there are bodies and proceedings which, although ostensibly qualifying as 'courts' and 'trials', have procedures that are so aberrant that they come to be regarded as courts and trials in name only. Hence the use of such terms as 'kangaroo court', 'show trial' or 'Star Chamber trial' to describe travesties of due process. ${ }^{34}$ In more marginal cases it is possible to say of a process that it ranks as a trial, albeit one that was 'unfair'. It is worth noting, however, that there does not exist a similar critical vocabulary as far as the term 'judicial function' is concerned. If a function does not merit the title 'judicial', it is simply categorised as 'legislative' or (more likely) 'administrative' in nature. ${ }^{35}$ 
As might be expected, it is revolutionary situations which provide excellent examples of procedures by reference to which the furthest limits of the institutions properly described as 'courts' or 'trials' can be explored. The legal processes employed by the Soviets are a case in point. In The Gulag Archipelago, Alexander Solzhenitsyn cites one N. V. Krylenko, who described the aims of the criminal courts that superseded the Tsarist codes. Krylenko is quoted as making a number of concessions: that a revolutionary tribunal was "not that kind of court [sc. a court that is occupied with questions of guilt or innocence]'; ${ }^{36}$ alternatively, that the tribunal was 'not a court at all' since 'a tribunal is an organ of the class struggle of the workers directed against their enemies' and must act 'from the point of view of the interests of the revolution ... having in mind the most desirable results for the masses of workers and peasants. ${ }^{37}$ There is, in this last remark, a frank recognition that certain bodies used by the Soviets were not merely informed by conceptions of law and procedure that were very different from those encountered in the West. Rather, they possessed no more than the outward appearance of a court.

Reference was made earlier to the scope afforded by international human rights documents, especially those to which countries throughout the world may subscribe and which are not confined to a particular continent, for exploring the essential characteristics of the trial. The International Covenant on Civil and Political Rights ${ }^{38}$ is uniquely placed in this respect for a number of reasons. It possesses a global compass, it is concerned with the classic liberties of Western political thought (among which trial guarantees figure prominently), and it is endowed with machinery - the Human Rights Committee - for interpreting the guarantees of the treaty. In the course of checking compliance with the standards of the Covenant, the Human Rights Committee has had occasion to scrutinise tribunals that exercise special jurisdictions (styled with names such as 'Comrades Courts', 'State Security Courts' and 'Public Security Committees' $)^{39}$ and also ordinary courts where the judges are required to follow revolutionary ideologies or the approved party line. ${ }^{40}$

Finally, it is literature which provides the best-known example of the perversion of procedures into a form scarcely recognisable as legal. Kafka's The Trial can be read at one level as a description of the nightmare of being subject to secret charges, before an unidentified court, with procedures that one cannot even begin to comprehend. The protagonist of the book, Joseph $\mathrm{K}$., is executed after a process - perhaps that would be too formal a term to apply to the disconnected series of events around which the novel is written which denies him the most basic information. What is the charge against him? Who is the accuser? How is K. to defend himself or his lawyer to defend him? What is the seat and who are the personnel of the court? Certainly, the vocabulary of law and legal systems is used. There has been an 'arrest': there is an 'examining magistrate': a 'lawyer' is consulted. Yet the reality falls well short of even the most extreme conceptions of legality and due process. 


\section{Three elements}

The above observations are preliminary in nature. The central aim of this section is to discuss three elements to be found in the conduct of trials. It is first necessary, however, to identify the general features of the trial process. These can be briefly stated: the accusation; the response to it of the accused; the interrogation of witnesses; argument, largely oral, on the factual and legal issues by the opposing sides, whether in person or through the medium of professional advocates; ${ }^{41}$ the culmination of the process in the delivery of judgment of the tribunal; and, if so required, the announcement of the sanction to be inflicted.

The bodies before which trials are held will usually have general jurisdiction. A tribunal that is specialised in regard to particular categories of person or types of offence, although suspect in some circumstances, is not in itself objectionable. ${ }^{42}$ Military personnel have traditionally been treated apart from the general courts, and courts-martial can readily be included in the category of 'trials' ${ }^{43}$ These are to be contrasted with procedures under disciplinary codes administered by such persons as commanding officers or prison governors. ${ }^{44}$ Although disciplinary procedures generally will include an opportunity for the subordinate to give an account of his conduct, and are capable of culminating in the imposition of sanctions, they are essentially summary in nature and lack the tripartite tension (prosecution, accused, judge) that is characteristic of the trial.

There is, in the concept of 'trial', a strong undercurrent of the idea of a contest. The trial is necessitated by the existence of a dispute - one that is resolved by the application of the law to the facts as authoritatively found and terminated by one side or the other securing the verdict of the court. The element of dispute may be removed at the very outset of the proceedings, because either an unequivocal concession of guilt is made or there is a negotiated admission of guilt on a lesser charge. From a historical point of view this is of little concern since the famous events of the past that are commonly referred to as 'trials' have involved issues that have been sharply contested between the opposing sides.

There is considerable variety as far as the structure of courts and the methodology of trials are concerned. Some courts are staffed by professional judges, others by laymen (or any combination in between). Many judicial officials are appointed, others are elected. A commonly drawn contrast is that between the adversarial and the inquisitorial modes of trial. In the former there is an unstated association of the trial with the conduct of a game or contest, the judge remaining relatively passive (as befits a referee). It rests on the supposition that the clash between the opposing parties is more likely than other methods to produce the truth. In the inquisitorial trial, by contrast, the judge is more active - $\mathrm{a}$ factor which reflects the need for a judicial investigation of the circumstances in which an alleged crime has been committed. In some 
legal systems the alleged victim, or his family, may be joined in the proceedings (the partie civile) for the purpose of gaining monetary compensation from the accused. Where this facility is not available, a separate action must be brought to obtain damages, with the possibility that the two proceedings may end in contradictory pronouncements as to whether or not a person was responsible for the act in question. ${ }^{45}$

The word 'trial' is also deployed in a number of figurative ways. It may be used to refer to the trial, not of a person, but of an inanimate object. Such, for example, is the so-called 'trial of the pyx' held at least once a year for the purpose of determining whether coins issued by the Mint have been made in accordance with the legislative requirements. ${ }^{46} \mathrm{~A}$ number of procedural steps are laid down by statute that are evocative of the trial of persons. ${ }^{47} \mathrm{~A}$ 'jury' is summoned and sworn; the proceedings are attended by the officers concerned of the various departments of state; and they conclude with the publication of a 'verdict'. All this is metaphorical usage since trials proper would require the participation in the proceedings, however minimal, of the accused. For that reason those societies, largely medieval, that staged 'trials' of animals must be accounted as having held trials in a figurative sense only. ${ }^{48}$

More generally, the term is used in an extended sense as signifying any inquiry into an alleged crime that is conducted outside the structured setting of a courtroom and which results in the informal 'acquittal' or (more likely) 'condemnation' of an individual by public opinion. The not infrequently voiced complaint of 'trial by media' uses the word in this sense. The Court of Appeal, for example, once heard an appeal against conviction by a person who had consented to being interviewed on television in connection with events for which he was eventually charged and convicted of fraud. The purpose of the interview, the Court of Appeal had no doubt, was to expose the person as guilty. Although it rejected the appeal, the court condemned the staging of the interview as wholly improper. 'Findings' of guilt (or innocence) would be made by the public on the basis of evidence and argument in the television studio, where the interviewee did not have the benefit of counsel or any of the procedural guarantees of a trial proper. "Trial by television', the Court of Appeal pronounced, 'is not to be tolerated in a civilized society'. ${ }^{49}$

The phrase "trial within a trial' ${ }^{50}$ is used to describe contests within a trial setting that are concerned with a specific, subsidiary issue: typically, the admissibility of an item of evidence. The first use of 'trial' in the expression is figurative, denoting a contest directed to that one matter and held in a different form (usually with the jury excluded) from the main trial event. As with the trial proper, the result of the 'trial within a trial' is victory for one side or the other.

To turn now to the central theme of this section, it is suggested that the following three elements are to be found in processes that are properly called trials. 


\section{Internal rationality}

In Bridges v. California, ${ }^{51}$ a case which raised the issue of the legality of outspoken comments reported in the press concerning a pending case, the majority judgment of the US Supreme Court pronounced:

The very word 'trial' connotes decisions on the evidence and arguments properly advanced in open court. Legal trials are not like elections, to be won through the use of the meeting-hall, the radio, and the newspaper ... ${ }^{52}$

As already noted, the idea of a trial at law - in contrast to "trial by the media' - implies a process marked by a controlled flow of material to the judges, on the basis of which they are to reach their verdict. The selection of that material is to be rationally related to the judgment eventually recorded. ${ }^{53}$ In modern times, however, the matching of means to end has been tempered by restraints that stem from the need to respect other values that are prized by the legal system. Both the general observation and the qualification to it require further comment.

The legal systems of the world vary considerably in the rules adopted by them in allowing or disallowing particular items of evidence. To take only one example, should the previous convictions of the accused be made available to the tribunal? Whatever the rules might be on this and other points, the failure of the trial court to follow them provides grounds for overturning a conviction. On a rare occasion, however, the verdict is quashed because the sequence of reasoning, without violating any particular rule of evidence, defies the basic ground rules of rationality for that system. A striking example is provided by a modern case in which some members of the jury in a trial for murder were led to their verdict of guilty as a result of taking soundings of a ouija board. ${ }^{54}$

The rationalistic matching of evidence to the question of the guilt or innocence of the accused is tempered by values associated with the liberty of the subject. This is a relatively modern phenomenon. It finds its clearest expression, at the point of drawing inferences from the evidence, in the presumption that the accused is innocent. More controversially, some legal systems impose constraints on the methods used in the fact-gathering process, thereby curbing the excesses of the investigating force. They might, for example, disallow the use at trial of evidence obtained illegally (or improperly) by the police, even in circumstances where the evidence is undoubtedly related to proof of the accused's guilt.

These observations on rationality as an aspect of trials presuppose societies where there is a sharp differentiation between social norms and legal norms, and the enforcement of the latter is attended by a distinctive formality. In some societies there exists no such distinction. Alternatively, the distinction may exist in large measure, while for the purposes of dealing with less serious misconduct a more informal court system is used, in which all aspects of a miscreant's personality and conduct might be capable of being aired. ${ }^{55}$ 
Even in the modern Anglo-American trial there exists one focal point at which considerations extraneous to the strict legal merits of a case are capable of intruding. This is the long-standing facility available to the jury to return a verdict of not guilty, even in the face of the clear guilt of the accused on the legal and factual merits, as a method of protesting against an oppressive law or its use on the occasion of a particular prosecution. ${ }^{56}$

Finally, a general consideration of rationality must devote some space to trial methods that, by modern lights, are extremely irrational. The medieval trial by ordeal, ${ }^{57}$ including trial by battle, ${ }^{58}$ springs readily to mind. However, these methods, even if not objectively true, were at least entirely rational when considered from the perspective of medieval belief systems. The processes rested on the belief, then widespread, that there existed a God who could intervene in human affairs in order to secure a just outcome. The ordeal, moreover, conferred finality on disputes in situations where the application of evidence (or, to be more precise, what is today regarded as evidence) was indeterminate. $^{59}$

\section{Publicity - trial as spectacle}

A further element of the processes known as trials is that, as an almost invariable rule, they take place in public. This is sometimes encapsulated in the cliché: 'Not only must justice be done, it must also be seen to be done.' The incidental benefit of this aspect has been the opportunity to record the trial events for posterity. In this way written accounts have been handed down of the two most famous trials of antiquity: in the gospels, and in the works, generally known as The Apology of Socrates, of Plato and Xenophon. ${ }^{60}$

What counts as being 'in public' varies according to the media of communication available in the epoch in question. In its basic form, the rule allows for the admission to the trial of casual spectators who have no connection with the proceedings other than a wish to observe them. With the rise of the print medium, this was extended to the conferral of special facilities for the representatives of the press: both in seating specially set aside for them and in the legal privileges attaching to the publication of their reports. It was especially important that reports of trial proceedings were privileged against actions for defamation since they would inevitably result in the dissemination beyond the courtroom of allegations which were damaging to the reputation of individuals. Finally, the growth of radio and television networks in the twentieth century has created the possibility of a global audience for the most prominent trials.

Among legal theorists, Jeremy Bentham devoted some attention to the question of why trials should take place in public. Publicity was seen by Bentham as a means of keeping the otherwise errant judge up to the mark:

[Publicity] keeps the judge himself, while trying, under trial ... So many bystanders as an unrighteous judge (or rather a judge who would otherwise have 
been unrighteous) beholds attending in his court, so many witnesses he sees of his own unrighteousness. ${ }^{61}$

He also saw it as a check on the dishonest witness:

Environed as [the witness] sees himself by a thousand eyes, contradiction, should he hazard a false tale, will seem ready to rise up in opposition to it from a thousand mouths. ${ }^{62}$

That the process was conducted in public, however, was as true of trial by ordeal as it is of the modern trial based on the testimony of witnesses. It has been pointed out that, from the perspective of gratifying the crowds in attendance, certain ordeals had the advantage over others. ${ }^{63}$ Trial by water yielded a quick result (as the person subject to the ordeal either sank or did not) as compared with trial by hot iron (with the three days' wait for the unbinding of the hand that had carried the iron, with the resulting dispersal and reassembling of the crowd).

Certain phases of the trial have been regarded as not regulated by the norm of publicity. The Anglo-American jury, in modern times at any rate, has pondered its verdict under conditions of secrecy - an arrangement that has never been regarded as violating the requirement of public trial. ${ }^{64}$ Again, the substantive hearing may be held in secret for reasons that are viewed as perfectly proper: for example, where evidence impinging on issues of national security is heard, or where matters relating to children are involved.

So close is the association between the idea of a trial and that of public access that the trial which takes place behind closed doors is regarded as fundamentally defective. Secret trials have notoriously been used by tyrannical regimes as a means of disposing of their opponents. ${ }^{65}$ Therefore it is not surprising that, with the promulgation of charters of human rights from the eighteenth century onwards, the generally accepted norm that trials were to be held in public was translated into the idea that the accused possessed a right to a public trial. ${ }^{66}$ Departures from the standard of open access are rightly regarded with suspicion. However, trial proceedings may equally be perverted by being saturated in publicity, thereby gaining the stigma of a 'show trial ${ }^{67}$

\section{Independence}

The third element is that of the independence, or autonomy, of the process of trial, both from government and from any of the parties. It is a point that appears to overlap with, but is quite distinct from, the element of rationality.

In the light of the association of trials with the exercise of state power, it should be recognised that complete independence of governmental structures is impossible. Judges are appointed, paid, and (if the circumstances warrant it) dismissed, by government. ${ }^{68}$ Yet, against that background, the idea of judicial independence exercises a strong hold. Landmark documents, principally the Act of Settlement 1701, are associated with the securing of that independence. 
Judges are not to be distracted from the internal logic of the trial by the fear of loss of position or reduction of pay. That the courts are part of, yet separate from, the institutions of government was reflected early in the seventeenth century, in Prohibitions del Roy ${ }^{69}$ In that leading case King James I was informed that, though he might be present in his court, he could not arrogate to himself the right to judge any case. Here, again, the theme subsequently found expression in human rights charters. These documents invariably require criminal charges to be tried before (to quote the standard phrase) 'an independent and impartial tribunal' ${ }^{70}$ The requirement of independence from government creates particular problems in those situations in the aftermath of war where the vanquished are tried by the victors. A case in point is the 'trial' of Charles I in 1649 by a court consisting of Members of Parliament that had been brought into existence specifically for the purpose of trying the king. ${ }^{71}$

Not only must the process be independent of government, it must also be (and, under a more stringent test, be seen to be) independent of the parties themselves. There are cases where the connection between a party and one of the personnel trying the issue is sufficiently strong to raise doubts as to whether the judgment of the latter has been diverted from the evidence and argument presented in court. The issue of natural justice raised here (nemo iudex in causa sua) is one which is pursued with varying degrees of vigour in the legal systems of the world. It figures sufficiently prominently in the United States to have been the subject of a substantial specialist work. ${ }^{72}$ It is raised relatively infrequently, by comparison, in the United Kingdom. ${ }^{73}$

\section{The functions served by trials}

One approach to the question, 'What is a trial?', is to answer it, not so much by identifying the formal features of the process, but rather in terms of the functions that are served by trials.

The central purpose is to arrive at a determination, whether that the person charged is guilty or that he is to be absolved from guilt. However, subsidiary purposes are also promoted, if only incidentally, by the trial proceedings. There is an element of education as the public is schooled in the workings of the judicial system. There is also an element of deterrence as the community takes note of the punishment meted out to those found guilty. That the trial takes place in public is essential to the achievement of these aims. In the words of Jeremy Bentham:

By publicity, the temple of justice is converted into a school of the first order, where the most important branches of morality are enforced, by the most impressive means ... ${ }^{74}$

The holding of a trial presupposes that there will have been a violation of one of the most fundamental norms of conduct of society. The investigation of 
the circumstances of that violation forms an additional focal point of the proceedings. There is, however, an array of procedural forums - inquests and inquiries - through which that element may be pursued apart from the trial itself.

Sometimes the use of the alternative forum is necessitated by the fact that, for various reasons, a trial is not possible or feasible. The prime suspect, for example, might have died before proceedings could be instituted. ${ }^{75}$ This was the situation after the assassination of President Kennedy. The circumstances of the murder were officially investigated in December 1963-September 1964 by a presidential commission chaired by the chief justice of the United States Supreme Court, Earl Warren. Sometimes a trial has taken place but the holding of another one is rendered impracticable either by reason of the severity of the punishment inflicted after the first event or on account of the difficulty of securing a second trial that would be fair. Both these factors account for the establishment of the Shipman inquiry. Dr Harold Shipman, a medical practitioner, was convicted in January 2000 at the Crown Court of the murder of fifteen of his patients. The terms of the inquiry, which began sitting in June 2001, were to investigate the circumstances of death of a considerably larger number of Dr Shipman's patients. In a replication of some of the features of the trial, the inquiry is being conducted in public and under the chairmanship of a High Court judge.

The investigative characteristics of a trial are to be found in the formal inquiry that is often set up in the aftermath of a disaster - though, of course, the same event may also be the focus of a number of criminal prosecutions or civil actions. In some areas (for example, maritime disasters) there is a specialist mechanism for conducting an investigation. Otherwise, a general investigatory power is contained in the Tribunals of Inquiry (Evidence) Act 1921. The tribunal that is set up under that Act possesses many of the powers that are usually associated with the jurisdiction of a court (e.g. a contempt power, the power to issue summonses for documents or witnesses). Although the tribunal itself cannot inflict punishment or make an award of damages, the report of the inquiry will often attribute blame for the event under investigation. The loss of reputation that may ensue from an adverse finding is such that the persons concerned will employ counsel to represent their interests at the hearing. In this way, where a formal investigation is held under the Merchant Shipping Act, the procedural rules stipulate that it is to be held in such a way that 'if substantial criticism is made against any person that person shall have an opportunity of making his defence either in person or otherwise'. ${ }^{76}$

The coroner's inquest is the most overtly judicial of the purely investigatory devices. There is a 'court', with a 'jury' that returns a 'verdict'. The nature of the proceedings is defined by the task of investigating the circumstances of an unexplained death - though, once again, the death may also 
form the subject of proceedings in a criminal or civil forum. The attribution of guilt is no longer one of the functions of a coroner's inquest under English law. ${ }^{77}$ However, where the circumstances suggest that death may have occurred as a result of an illegal act, the investigation in the course of the inquest proceedings may implicate, or exonerate, particular individuals. A famous contemporary example is furnished by the 'dingo' case in Australia in the 1980s. When an infant disappeared from a camp site the parents, Lindy and Michael Chamberlain, fell under suspicion. They maintained that the baby had been dragged away by a dingo (a type of wild dog). Inquest proceedings were held, as a result of which they were pronounced blameless. The production of further evidence, however, led to the Chamberlains being indicted and convicted of murder. The balance shifted as between the competing explanations of the baby's disappearance when a royal commission produced substantial material on the propensity of dingoes to attack babies. The Chamberlains' convictions were consequently quashed. The episode vividly illustrates how the process of investigation of the circumstances of an alleged crime can be pursued in several forums - not only the trial itself, but also a coroner's inquest and (most unusually) a royal commission. ${ }^{78}$

\section{Concluding comments}

The purpose of this introductory chapter has not been to provide a stipulative definition of the word 'trial'. Any definition would be vulnerable to the production of examples to the contrary from the judicial procedures of mankind. The answer to the question, 'What is a trial?', cannot be resolved by verbal fiat. Yet something should be said about those legal proceedings which have been excluded from consideration here. Some of the most famous cases have been those where the facts were scarcely in dispute while the legal issues that dominated the argument had far-reaching consequences, not only for the parties to the case, but also (and much more significantly) for the society in which they were litigated. As is to be expected, such cases are most frequently encountered in legal systems where the courts exercise the power of constitutional review. Examples would include such decisions of the US Supreme Court as Brown v. Board of Education of Topeka, ${ }^{79}$ in which racial segregation in the public school system was declared illegal, and also the Dred Scott case, ${ }^{80}$ the ruling in which was responsible for precipitating the American Civil War.

Rather, the focus of this chapter has been those cases, largely criminal cases, which have been contested in courts of first instance (in contrast to appellate courts). The proceedings, even if they have also raised difficult questions of law, have at least involved disputed issues of fact and their interpretation. For the word 'trial' is fixed in the public mind with judicial procedures which, in the course of resolving those issues, decide the fortunes of particular individuals. 


\section{Notes}

1 Constitution of the United States, Sixth Amendment.

2 European Convention on Human Rights, Article 6(1): 'In the determination of his civil rights and obligations or of any criminal charge against him, everyone is entitled to a fair and public hearing ...' See, also, the Universal Declaration of Human Rights 1948, Article 10: 'Everyone is entitled in full equality to a fair and public hearing by an independent and impartial tribunal, in the determination of his rights and obligations and of any criminal charge against him.' Also, the International Covenant on Civil and Political Rights 1966, Article 14 (1): ' . . In the determination of any criminal charge against him, or of his rights and obligations in a suit at law, everyone shall be entitled to a fair and public hearing ...'

3 Constitution of the United States, Sixth Amendment. See also the guarantees of a 'fair and public hearing' set out in n. 2, above.

4 Constitution of the United States, Seventh Amendment.

5 The original text reads: 'per legale judicium parium suorum'.

6381 U.S. 532 (1965).

7 Ibid., p. 559.

8 European Convention on Human Rights, Article 7.

9 Constitution of the United States, Fifth Amendment.

10 Constitution of the United States, Eighth Amendment.

11 Ibid.

12 In those documents that prohibit certain types of treatment or punishment there is no pressing need to elucidate the concept of punishment as long as the other concept (e.g. 'treatment') is sufficiently wide. The link with the institution of trial is therefore less direct. Such, for example, is the situation under the European Convention on Human Rights, Article 3: 'No one shall be subjected to torture or to inhuman or degrading treatment or punishment'.

13 Constitution of the United States, Sixth Amendment; European Convention on Human Rights, Article 6, paragraph 3(c).

14 J. H. Baker, The Legal Profession and the Common Law: Historical Essays (London, 1986), chapter 10 ('The changing concept of a court').

15 Ibid., pp. 155-6.

16 Cf. Baker's classification of court as jurisdiction, court as an institution, and court as a corporate body.

17 Ibid., p. 156.

18 For a brief account of natural justice, see P. Cane, An Introduction to Administrative Law (third edition, Oxford, 1996), pp. 160-92.

19 S. A. de Smith, H. Woolf and J. Jowell, Judicial Review of Administrative Action (fifth edition, London, 1995), pp. 1011-19.

20 It is worth recording that the Notable British Trials series appears to work on the same basis. Although the majority of the cases in that series are criminal prosecutions, it covers other types of case besides. There is, for example, a volume on the 'Baccarat case' of 1891: W. T. Shore (ed.), The Baccarat Case (London and Edinburgh, 1932). This was an action for slander, brought to refute an allegation of cheating at cards, by Sir William Gordon-Cumming. The case gained considerable attention partly because the Prince of Wales, the future Edward VII, gave evidence in the proceedings. On losing the case, Gordon-Cumming was socially ostracised. 
21 Sir Charles Dilke was cited as co-respondent in a divorce suit brought in 1886 . The case is remarkable because it is generally agreed among historians that he was not guilty of the charge of adultery. At the time, however, a husband could gain a divorce simply on the basis of a confession of adultery by his wife. The consequences for Dilke's career are embodied in the title of a modern biography: D. Nicholls, The Lost Prime Minister (London, 1995).

22 In the trial for manslaughter, in December of that year, of Lord de Clifford.

23 By the Criminal Justice Act 1948. On the early history of the institution, see L. W. Vernon Harcourt, His Grace The Steward and Trial of Peers (London, 1907).

24 See, for example, E. A. Smith, A Queen on Trial: The Affair of Queen Caroline (Dover, New Hampshire, 1993). Cf. R. A. Melikan, 'Pains and penalties procedure: how the House of Lords “tried” Queen Caroline', Parliamentary History, 20 (2001), 15576. A version of this article also appears in R. A. Melikan (ed.), Domestic and International Trials, 1700-2000 (Manchester, 2003).

25 See Smith, Queen on Trial, pp. 133-4 for the text of the Bill.

26 See R. Berger, Impeachment: The Constitutional Problems (Cambridge, Massachusetts, 1974), pp. 82-90, for an examination of the question whether impeachment is a criminal proceeding.

27 Article II, section 4.

28 Article III, section 2, clause 3.

29 Article I, section 3, clause 6.

30 The same special majority is required in the US Constitution for such clear political purposes as overriding a presidential veto of a congressional bill. It was the twothirds majority requirement that was responsible for the narrow defeat of the impeachment process against President Johnson, by 35 to 19 votes.

31 Article I, section 9, clause 3: 'No Bill of Attainder or ex post facto Law shall be passed.'

32 E. Dumbauld, The Constitution of the United States (Oklahoma, 1964), p. 195. See, also, U.S. v. Brown 381 US 437 (1965), at p. 441: "The bill of attainder, a parliamentary act sentencing to death one or more specific persons, was a device often resorted to in sixteenth, seventeenth and eighteenth century England for dealing with persons who had attempted, or threatened to attempt, to overthrow the government.' In the Brown case, a provision that made it a criminal offence for a member of the Communist Party to serve as an official or employee of a trade union was held to be caught by the 'Bill of Attainder' provision of the Constitution (n. 31, above).

33 D. Somervell, 'Acts of Attainder', Law Quarterly Review, 67 (1951), 309. Sometimes, an Act of Attainder was used to declare forfeit the estates of one who had participated in a rebellion but who, being dead, could no longer be brought to trial: ibid., 306-7.

34 Of the three pejorative terms, however, 'kangaroo court' tends to be used of disciplinary proceedings of private groups and associations rather than of the court system administered by the state.

35 In the tripartite division of governmental powers, the 'administrative' category appears to function as one that is residuary, encompassing those processes that do not fit into either of the other two categories.

36 A. Solzhenitsyn, The Gulag Archipelago 1918-1956: An Experiment in Literary Investigation (2 vols, London, 1974), p. 308. 
37 Ibid.

38 The Covenant entered into force in 1976, having been approved by the General Assembly of the United Nations ten years earlier.

39 See D. McGoldrick, The Human Rights Committee: Its Role in the Development of the International Covenant on Civil and Political Rights (Oxford, 1991), p. 399.

40 Ibid., p. 401.

41 From the perspective of the accused many of these elements embody the right to a hearing (audi alteram partem).

42 See R. Furneaux, Great Issues in Private Courts (London, 1964) for an account of some notable proceedings before tribunals, many of them established under statutory authority, which have tried charges of disciplinary misconduct by members of such groups as barristers, medical practitioners and clergymen.

43 Notorious instances include those against Captain Dreyfus in France (in 1894) and Admiral Byng in England (in 1757).

44 Sometimes the misconduct in question might have been charged before the ordinary courts if the offender had not been a soldier or prisoner. Sometimes there is no equivalent penalty under ordinary law, since the provision of the disciplinary code is aimed solely at the smooth functioning of the organisation (whether armed forces or prison).

45 As happened in the case of O. J. Simpson, who, having been acquitted in the criminal proceedings, was later held liable in damages.

46 The term 'pyx' refers, not to the coins themselves, but rather to the box in which the specimen coins are contained.

47 They are set out in section 8 of the Coinage Act 1971.

48 See, generally, E. Cohen, 'Law, folklore and animal lore', Past and Present, no. 110 (1986), 6-37.

49 Regina v. Savundranayagan and Walker [1968] 3 All E.R. 439, p. 441H.

50 There is a monograph on the subject under the law of Malaysia and Singapore: S. A. Paul, Trial within a Trial (Harmonden, Kent, 1994).

51314 U.S. 252 (1941).

52 Ibid., at p. 271.

53 As with the other two features, considered below, the standard of rationality is imposed in areas of government apart from the conduct of trials. For example, it is increasingly common for the English courts, when exercising judicial review over administrative decision-making, to annul decisions on the ground of their irrationality.

54 Regina v. Young (Stephen) [1995] Q.B. 324.

55 As, for example, in the comrades' courts of Soviet Russia: see Y. Gorlizki, 'Delegalization in Russia: Soviet Comrades' Courts in retrospect', American Journal of Comparative Law, 46 (1998), 421-2.

56 See P. Devlin, Trial by Jury (London, 1956), pp. 160-5, and W. R. Cornish, The Jury (Harmondsworth, 1968), chapter 5.

57 R. Bartlett, Trial by Fire and Water: The Medieval Judicial Ordeal (Oxford, 1986).

58 Ibid., chapter 6. It was abolished in England by statute in 1819.

59 Ibid., pp. 157-66. See, also, D. Daube 'The scales of justice', Juridical Review, 63 (1951), 123-6, for the (unsubstantiated) view that the early prevalence of trial by ordeal - in which there was a clear winner and a clear loser - was conducive to the emergence of litigation that was characterised by winner-take-all outcomes. 
60 In each case the Apology purports, rather, to recount Socrates' speech in his own defence. Of course, the extent to which these works provide accurate summaries of the trials of Jesus and Socrates, free of the interpretations of their followers, has long been controversial.

61 Jeremy Bentham, 'Rationale of judicial evidence, specially applied to English practice', in J. Bowring (ed.), The Works of Jeremy Bentham (11 vols, Edinburgh, 1843), VI, p. 355.

62 Jeremy Bentham, 'Draught of a code for the organization of the judicial establishment in France', in Bowring (ed.), Works, IV, p. 317.

63 Bartlett, Trial, p. 23.

64 In the United Kingdom it has been a criminal offence since the passage of the Contempt of Court Act 1981 to disclose, or even to solicit, particulars of statements, opinions, or arguments expressed, or votes cast, in the course of jury deliberations. In the USA, on the other hand, it is notorious that members of the jury in newsworthy trials are free to reveal such details, to their financial advantage, once the case is concluded.

65 H. H. Scullard, From the Gracchi to Nero: A History of Rome 133 BC to AD 68 (fifth edition, London, 1982), p. 304, recalls the early optimism attending the emperor Nero's reign in his promising, among other things, to put an end to secret trials intra cubiculum.

66 For modern statements to that effect see n. 2, above. It is an idea that I have argued to be philosophically unintelligible: see J. Jaconelli, 'Rights theories and public trial'; Journal of Applied Philosophy, 14 (1997), 169-75.

67 To describe an event as a 'show trial' is not necessarily to conclude that the accused was wrongly convicted, or that the charge was unworthy of a civilised legal system. A good example is provided by the trial of the U2 pilot, Gary Powers, in 1960 before nearly a thousand spectators in Moscow's Hall of Columns. The trial, at one level, was entirely fair. There can be no doubt that Powers had been on a spying mission when his plane was shot down over the Soviet Union. The event can nevertheless be regarded as a show trial since its primary aim was to serve the ends of the Soviet regime at a particularly fraught stage of Cold War diplomacy.

68 In some legal systems judges are subject to popular election. But even this presupposes the existence of state rules regulating the conduct of elections.

69 (1607) 12 Co. Rep. 63: 77 E. R. 1342.

70 The phrase used in Article 10 of the Universal Declaration of Human Rights; in Article 6, paragraph 1, of the European Convention on Human Rights; and, with a slight variation, in Article 14 of the International Covenant on Civil and Political Rights.

71 A well-known account is C. V. Wedgwood, The Trial of Charles I (London, 1964), chapters 6 and 7 .

72 R. E. Flamm, Judicial Disqualification: Recusal and Disqualification of Judges (Boston, Massachusetts, 1996).

73 The issue has been raised most recently, and dramatically, in the legal proceedings concerning the attempt to secure the extradition of the former dictator of Chile, General Pinochet: Regina v. Bow Street Metropolitan Stipendiary Magistrate, ex parte Pinochet Ugarte (No 2) [1999] 1 All E.R. 577. The case is particularly striking since the House of Lords set aside one of its own judgments as tainted by possible bias before rehearing the appeal in front of a differently constituted panel of judges. 
74 Bentham, 'Draught', in Bowring (ed.), Works, IV, p. 317.

75 Rather different is the situation where the prime suspect is not apprehended. Some legal systems permit trial in those circumstances to take place in absentia.

76 Merchant Shipping (Formal Investigations) Rules 1985, S.I. 1985 No 1001, section 9, promulgated under the Merchant Shipping Act 1970.

77 In 1975, before the relevant change in the law, a coroner's jury returned a verdict that Lord Lucan, who had disappeared the previous year and has never been traced, was guilty of the murder of the family's nanny.

78 Lindy Chamberlain published an account of the case in Through My Eyes: An Autobiography (London, 1991).

79347 U.S. 483 (1954).

80 Dred Scott v. Sandford 19 How. 393 (1857). 